\title{
The hockey-stick sign in a patient with unilateral proptosis
}

\author{
Saroj Gupta, ${ }^{1}$ Rakesh Biswas² \\ ${ }^{1}$ Department of Ophthalmology, People's College of Medical Sciences and Research Centre, Bhopal, India \\ ${ }^{2}$ Department of Medicine, People's College of Medical Sciences and Research Centre, Bhopal, India
}

Correspondence to Rakesh Biswas, rakesh7biswas@gmail.com

\section{DESCRIPTION}

A 23-year-old man presented with left-sided headache, protrusion of eye ball and hearing of some abnormal gurgling sound within the head for a period of 1 month. There was no history of trauma, collagen disorder or hypertension.

On examination, the right eye was normal. In the left eye, however, there was axial proptosis with dilated and tortuous conjunctival blood vessels (figure 1). Pulsations could be felt over the eye ball and a bruit was also audible.
Fundus showed dilated tortuous veins, with superficial haemorrhages near optic disc. Intraocular pressure (IOP) was $34.0 \mathrm{~mm} \mathrm{Hg}$ in the left eye.

Ultrasonography with colour Doppler of left orbit showed dilated, arterialised, superior ophthalmic vein (SOV) with flow reversal (figure 2). Contrast axial CT scan demonstrated intense enhancement of dilated left SOV with characteristic 'hockey-stick sign' (figure 3A). Cavernous sinus was enlarged, and there was hypertrophy of

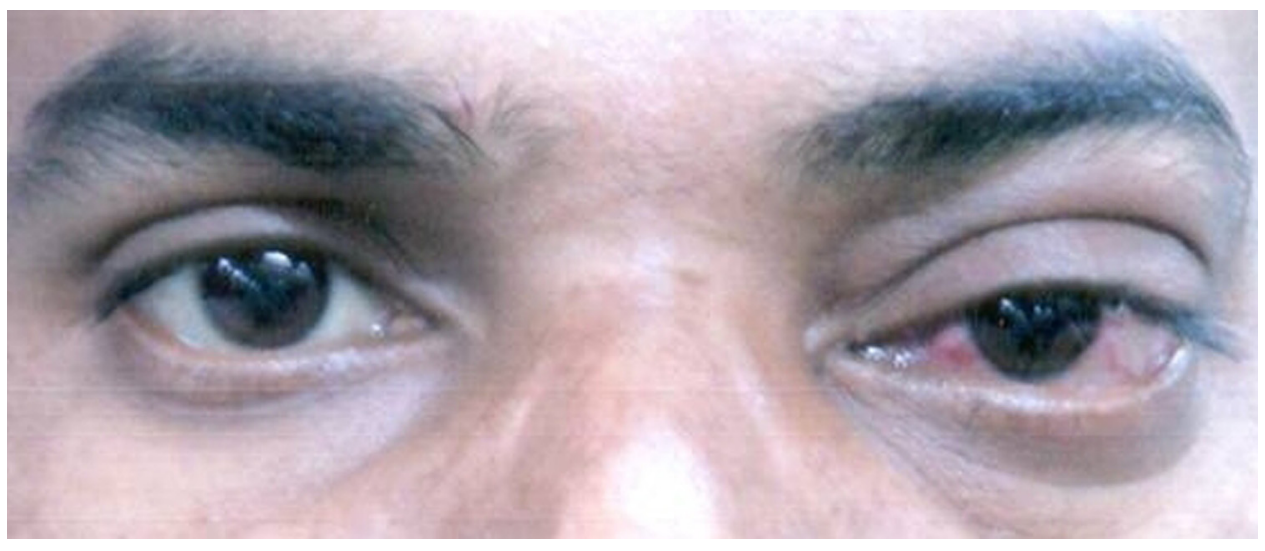

Figure 1 Clinical photograph showing axial proptosis with dilated episcleral veins on left side.

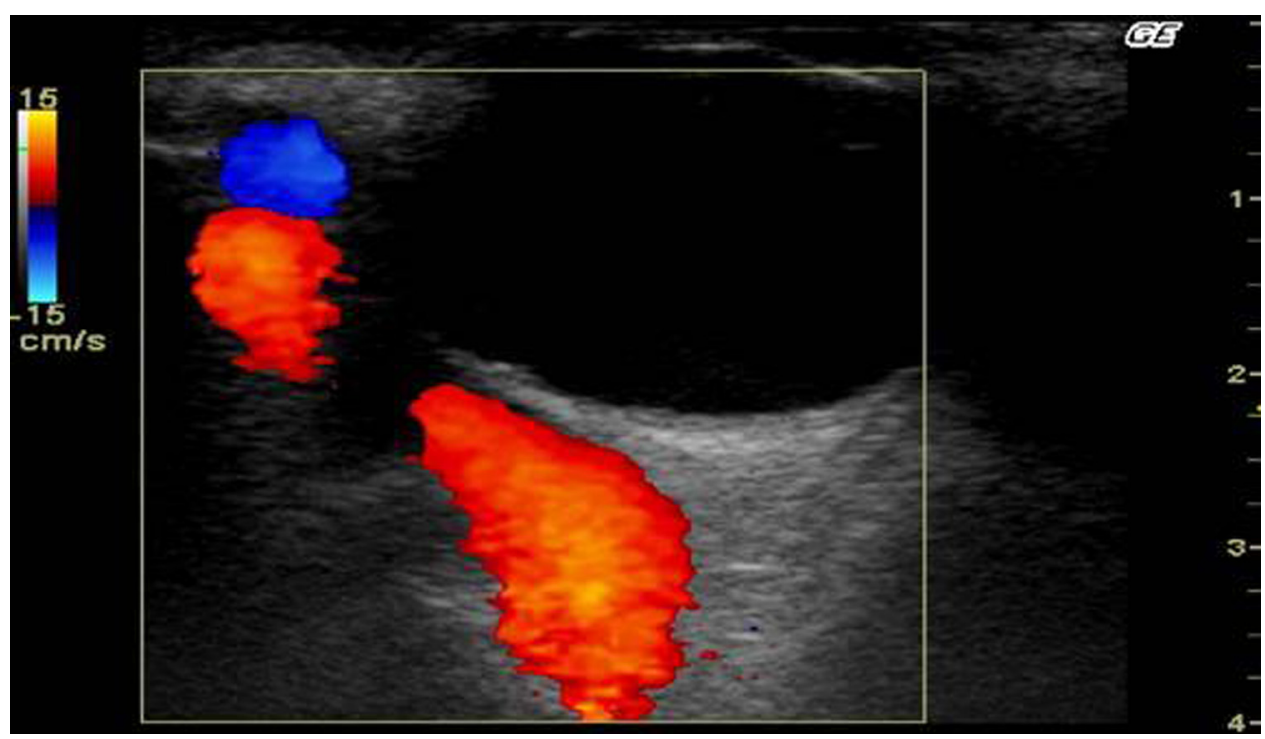

Figure 2 Ultrasonography with colour Doppler image of left orbit showing dilated, arterialised, superior ophthalmic vein. Flow reversal within vein is demonstrated in red colour. 


\section{BMJ Case Reports}
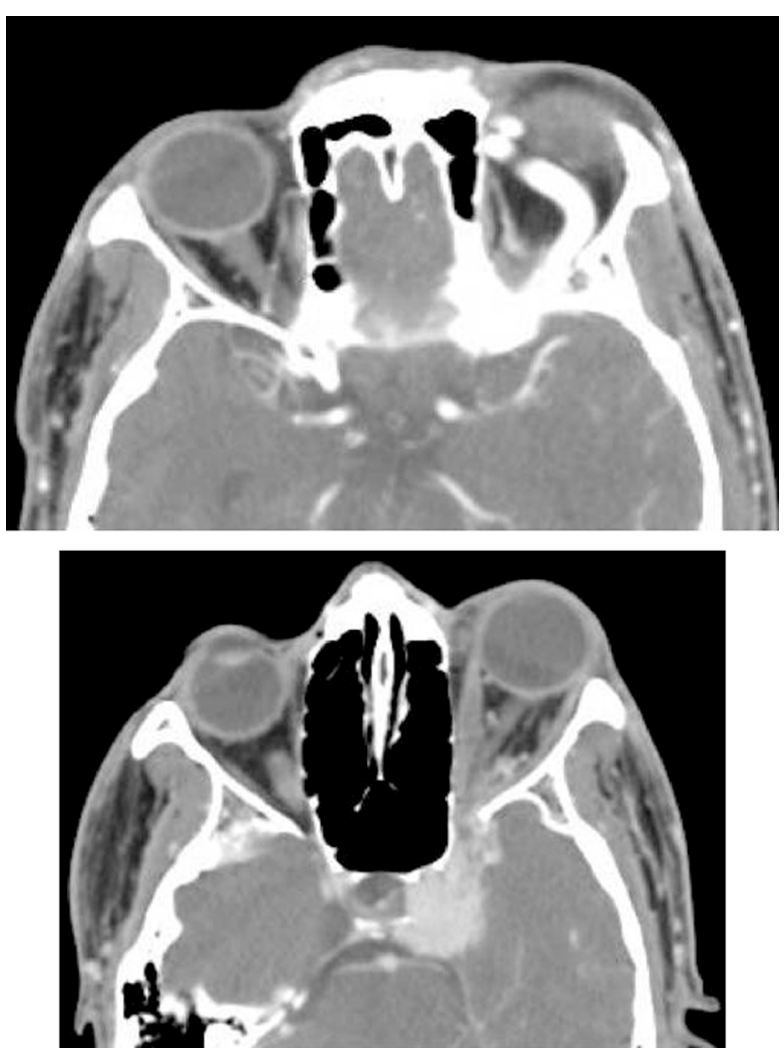

Figure 3 (A) Contrast-enhanced axial CT showing dilated left superior. Ophthalmic vein with characteristic 'hockey-stick sign'. (B) Contrast-enhanced axial CT showing enlarged cavernous sinus, dilated orbital fissure with hypertrophy of extra-ocular muscles and varices at orbital apex on the left side.

extra-ocular muscles with varices at orbital apex on left side (figure 3B). Digital subtraction angiography revealed a high-flow, direct carotid cavernous sinus fistula (CCF) (figure 4).

Patient was put on a combination of timolol $0.5 \%$ and bimatoprost $0.03 \%$ eye drops once a day to control the IOP. Then he underwent transvenous embolisation of CCF with detachable balloons to close the fistula. Three months after embolisation, the patient presented with normal IOP and resolution of all signs and symptoms.

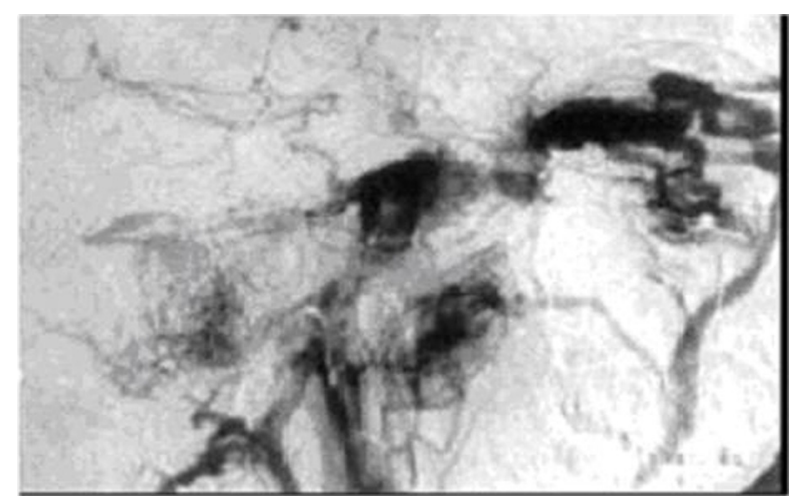

Figure 4 Digital subtraction angiography image showing a high-flow, direct carotid cavernous sinus fistula.

\section{DISCUSSION}

A high index of suspicion is the key factor in diagnosing a case of CCF without any history of trauma and collagen vascular disease. Approximately $25 \%$ of the CCF is of the spontaneous variety. ${ }^{1}$

In CCF the arterial pressure is directly transmitted to the orbital veins; therefore, there is venous congestion and decreased arterial perfusion to the globe. Both these events lead to the classical signs and symptoms of severe ipsilateral headache, homolateral carotid bruit, pulsating exophthalmos, dilated episcleral veins and increased IOP due to raised episcleral venous pressure. ${ }^{2} \mathrm{CT}$ and MRI are useful screening tools, which may show dilatation of the superior ophthalmic vein $(80 \%)$, increased extra ocular muscle size $(65 \%)$, or enlargement of cavernous sinus $(35 \%){ }^{3}$

Acknowledgement To all those who cared for this patient.

Competing interests None.

Patient consent Obtained.

\section{REFERENCES}

1. Das JK, Medhi J, Bhattacharya P. et al. Clinical spectrum of spontaneous carotid cavernous fistula. Indian J Ophthalmol 2007;55:310-12.

2. Westlack W. Vascular malformation. In: Easty DL, Sporow JM, eds. Oxford text book of ophthalmology. Vol II. Section 2.12.4. New York:Oxford University Press, 1992:896-7.

3. Rootman J, Marotta TR, Graeb DA. Vascular lesions. In: Rootman J, ed. Diseases of the orbit - a multi disciplinary approach. 2nd edn. Philadelphia, PA:Lippincott, Williams and Wilkins, 2003:532-9. 


\section{BMJ Case Reports}

This pdf has been created automatically from the final edited text and images.

Copyright 2010 BMJ Publishing Group. All rights reserved. For permission to reuse any of this content visit

http://group.bmj.com/group/rights-licensing/permissions.

BMJ Case Report Fellows may re-use this article for personal use and teaching without any further permission.

Please cite this article as follows (you will need to access the article online to obtain the date of publication).

Gupta S, Biswas R. The hockey-stick sign in a patient with unilateral proptosis. BMJ Case Reports 2010;10.1136/bcr.12.2009.2577, date of publication

Become a Fellow of BMJ Case Reports today and you can:

- Submit as many cases as you like

Enjoy fast sympathetic peer review and rapid publication of accepted articles

- Access all the published articles

- Re-use any of the published material for personal use and teaching without further permission

For information on Institutional Fellowships contact consortiasales@bmjgroup.com

Visit casereports.bmj.com for more articles like this and to become a Fellow 